\title{
Blocking rhinoviral adhesion molecule (ICAM-I): potential to prevent COPD exacerbations
}

\author{
This article was published in the following Dove Press journal: \\ International journal of COPD \\ II May 2017 \\ Number of times this article has been viewed
}

\author{
Shakti Dhar Shukla ${ }^{1-3}$ \\ Philip Michael Hansbro'-3 \\ Eugene Haydn Walters ${ }^{4}$ \\ 'Priority Research Centre for \\ Healthy Lungs, ${ }^{2} \mathrm{School}$ of Biomedical \\ Sciences and Pharmacy, The University \\ of Newcastle, Newcastle, NSW, \\ Australia; ${ }^{3}$ Hunter Medical Research \\ Institute, New Lambton Heights, \\ NSW, Australia; ${ }^{4}$ School of Medicine, \\ University of Tasmania, Hobart, TAS, \\ Australia
}

Correspondence: Eugene Haydn Walters School of Medicine, University of Tasmania, 17 Liverpool Street, Private Bag 23, Hobart, TAS 7000, Australia Email haydn.walters@utas.edu.au

\section{Dear editor}

Acute exacerbations of COPD (AECOPD) are markers of disease progression and severity, and frequently are used as an outcome variable in interventional studies. ${ }^{1}$ AECOPD results in increased severity of symptoms and induces disease progression with accelerated decline in lung function and decreased quality of life. The risk of morbidity and mortality is also significantly increased. Most AECOPD $(\sim 85 \%)$ have an infectious etiology, induced by bacteria and viruses, often rhinovirus $(\sim 50 \%){ }^{1}$

The paper by Johnston et $\mathrm{al}^{2}$ again emphasized the importance of the common cold and rhinoviruses in AECOPD. They found that cold-like symptoms are a reliable predictor of exacerbations in patients with COPD, occurring in over $80 \%$, although actual viral detection occurred in less than half of these. Notably, the group with virus positivity exhibited more severe symptoms than other groups. They emphasized the need to better understand the relationship between rhinovirus and COPD.

Approximately $60 \%$ of human rhinoviruses serotypes adhere to the intercellular adhesion molecule-1 (ICAM-1). Recently, we showed that airway epithelial ICAM-1 expression is upregulated throughout the respiratory tract in smokers, and is further increased in subjects with chronic airflow obstruction (including frank COPD), even when mild. Interestingly, ICAM-1 expression in goblet cells and submucosal glands in the airway wall was also markedly increased. Furthermore, cultured bronchial epithelial cells exposed to cigarette smoke extract exhibited significantly increased levels of ICAM-1, both at mRNA and protein levels. ${ }^{3}$ We suggest that such changes in pathogen adhesion sites may explain the increased vulnerability of COPD patients to virally induced exacerbations, which is otherwise essentially unexplained.

The issue of the potential importance of the upregulation of respiratory epithelial adhesion sites as a cause of certain specific bacteria and viruses being able to gain a serendipitous special niche in the airways in COPD needs much more attention, as it may open a potentially new nonantibiotic mode of prevention and treatment. ${ }^{4}$ Haemophilus influenzae and Streptococcus pneumoniae are prominent in respiratory tract infection in smokers/COPD and are also associated with exacerbations. This may well relate to hyper-upregulation of their co-opted major airway epithelial adhesion molecule, the platelet-activating factor receptor. Platelet-activating factor receptor blockers were developed over 20 years ago for the anti-inflammatory treatment of asthma, and proved safe but ineffective; they should now be trialed for this different indication. ${ }^{5}$ 
Moreover, the data provided by Johnston et al ${ }^{2}$ suggest that an anti-ICAM-1 molecule given at an early stage of a common cold in frequent exacerbations of COPD could potentially have a prophylactic effect against these devastating and expensive events.

\section{Disclosure}

The authors report no conflicts of interest in this communication.

\section{References}

1. Kurai D, Saraya T, Ishii H, Takizawa H. Virus-induced exacerbations in asthma and COPD. Front Microbiol. 2013;4:1-12.
2. Johnston NW, Olsson M, Edsbäcker S, et al. Colds as predictors of the onset and severity of COPD exacerbations. Int J Chron Obstruct Pulmon Dis. 2017;12:839-848.

3. Shukla SD, Mahmood MQ, Weston S, et al. The main rhinovirus respiratory tract adhesion site (ICAM-1) is upregulated in smokers and patients with chronic airflow limitation (CAL). Respir Res. 2017;18(6): $1-10$.

4. O'Toole RF, Shukla SD, Walters EH. Does upregulated host cell receptor expression provide a link between bacterial adhesion and chronic respiratory disease? J Transl Med. 2016;14(1):304.

5. Shukla SD, Sohal SS, O’Toole RF, Eapen MS, Walters EH. Platelet activating factor receptor: gateway for bacterial chronic airway infection in chronic obstructive pulmonary disease and potential therapeutic target. Expert Rev Respir Med. 2015;9(4):473-485.

Dove Medical Press encourages responsible, free and frank academic debate. The content of the International Journal of Chronic Obstructive Pulmonary Disease 'letters to the editor' section does not necessarily represent the views of Dove Medical Press, its officers, agents, employees, related entities or the International Journal of Chronic Obstructive Pulmonary Disease editors. While all reasonable steps have been taken to confirm the content of each letter, Dove Medical Press accepts no liability in respect of the content of any letter, nor is it responsible for the content and accuracy of any letter to the editor.

\section{Publish your work in this journal}

The International Journal of COPD is an international, peer-reviewed journal of therapeutics and pharmacology focusing on concise rapid reporting of clinical studies and reviews in COPD. Special focus is given to the pathophysiological processes underlying the disease, intervention programs, patient focused education, and self management protocols.

\section{Dovepress}

This journal is indexed on PubMed Central, MedLine and CAS. The manuscript management system is completely online and includes a very quick and fair peer-review system, which is all easy to use. Visit $\mathrm{http} / / / \mathrm{www}$.dovepress.com/testimonials.php to read real quotes from published authors. 